\title{
New antihistamines - perspectives in the treatment of some allergic and inflammatory disorders
}

Jan Tatarkiewicz ${ }^{1}$, Przemysław Rzodkiewicz ${ }^{2,3}$, Małgorzata Żochowska ${ }^{1}$, Anna Staniszewska ${ }^{4}$, Magdalena Bujalska-Zadrożny ${ }^{1}$

${ }^{1}$ Department of Pharmacodynamics, Centre for Preclinical Research and Technology, Medical University of Warsaw, Warsaw, Poland

2Department of Biochemistry and Molecular Biology, National Institute of Geriatrics, Rheumatology and Rehabilitation, Warsaw, Poland

${ }^{3}$ Department of General and Experimental Pathology, Medical University of Warsaw, Warsaw, Poland

${ }^{4}$ Department of Experimental and Clinical Pharmacology, Medical University

of Warsaw, Warsaw, Poland

Submitted: 6 October 2016

Accepted: 13 March 2017

Arch Med Sci 2019; 15, 2: 537-553

DOI: https://doi.org/10.5114/aoms.2017.68534

Copyright $\odot 2019$ Termedia \& Banach

\section{Introduction}

Histamine $[\mathrm{H}]$ is a well-known biogenic amine whose biological properties were first characterized more than 100 years ago [1, 2]. It plays a significant role in the human organism as a mediator and neurotransmitter. Histamine is produced in many types of tissues including immune cells, gastric mucosa, central nervous system (CNS), smooth muscles, sensory nerves, heart, etc. Histamine-producing cells may be divided into two types: professional and non-professional [3]. Professional histamine-producing cells such as mast cells, basophils, enterochromaffin-like cells of the gastric mucosa, and histaminergic neurons synthesize this mediator, collect it in special granules inside the cells and release it in large amounts after specific stimulation. In non-professional histamine-producing cells, histamine is synthesized and crosses the cell membrane with specific carrier proteins according to the concentration gradient. The non-professional histamine-producing cells include many other cell types, among them dendritic cells (DCs) [4] and T cells [5].

Histamine is involved in numerous physiological and pathophysiological processes [6] - immunological response, immunomodulation, inflammation, allergic response, gastric acid secretion, cell proliferation, wound healing, cognitive function, memory, sleep cycle, endocrine homeostasis - and has an influence on release of other neurotransmitters [7] and modulation of tumor growth [8].

Histamine exerts its effect through four types of G-protein coupled receptors: $\mathrm{H} 1, \mathrm{H} 2, \mathrm{H} 3$, and $\mathrm{H} 4[6,7,9,10]$. Histamine interacts with its receptors with different affinities. The most susceptible are histamine $\mathrm{H} 3$ and $\mathrm{H} 4$ receptors ( $\mathrm{H} 3 \mathrm{Rs}$ and $\mathrm{H} 4 \mathrm{Rs}$, respectively), whereas the activation of $\mathrm{H} 1$ and $\mathrm{H} 2$ receptors ( $\mathrm{H} 1 \mathrm{Rs}$ and $\mathrm{H} 2 \mathrm{Rs}$, respectively) requires significantly higher concentrations of histamine [11]. It is suggested that in some disorders in which classic antihistamines (i.e. drugs antagonizing histamine effects at $\mathrm{H} 1$ receptors) were not effective, it might be possible to control them using novel histamine receptor ligands acting at $\mathrm{H} 3$ and/ or $\mathrm{H} 4$ receptors $[6,12]$.

\author{
Corresponding author: \\ Anna Staniszewska MD, PhD \\ Department of \\ Experimental and \\ Clinical Pharmacology \\ Medical University \\ of Warsaw \\ 1 B Banacha St \\ 02-097 Warsaw, Poland \\ Phone: +48 502952507 \\ E-mail: annastaniszewska@ \\ poczta.fm
}




\section{Methods of review}

The authors searched the electronic database MEDLINE (PubMed, https://www.ncbi.nlm.nih. gov/pubmed/; until January $15^{\text {th }}, 2017$ ) using the following population search terms: $\mathrm{H} 3 \mathrm{OR} \mathrm{H} 4$ combined using the Boolean operator AND with the term receptor*. These search results were focused by combination using the Boolean operator AND with the terms "Histamine Antagonists/ pharmacology "[MeSH Terms] OR "Histamine Antagonists"[nm]. Results were further limited by combining (Boolean operator AND) with the aggregated (OR Boolean operator) terms related to allergic or inflammatory disorders. The following words were used as keywords: allerg*, hay fever, pollinosis, dermat*, dermatitis, dermatoses, atopic, rhinitis, rhinorrhea, conjunctiv*, rhinoconjunctivitis, prurit ${ }^{\star}$ itch, itching, sneezing, urticaria, congest*, asthma, cutaneous, flare, inflamm*, anaphylaxis, anaphylactic, shock, antinocicep*, nocicep*, pain*. Finally, reference lists from the resulting publications were manually searched for any relevant trials for elimination of results not related to the article topic. The resulting list of publications was limited to include only English, German, French and Spanish language publications (or at least papers with abstracts in one of the mentioned languages). Independently of the search described above, two important databases, ClinicalTrials.gov (https://clinicaltrials.gov) and EU Clinical Trials Register database (https://www. clinicaltrialsregister.eu) gathering clinical trials' results were searched using a similar strategy in order to find clinical trials not published elsewhere. In case of any doubts, also individual companies' web sites as well as the whole Internet were searched using the Google browser.

\section{The role of histamine and its receptors in allergy and inflammation}

Several immunological or non-immunological factors result in activation of histamine-producing cells and their degranulation. This biogenic amine is synthesized mainly by mast cells and basophils. The predominant storage site for histamine in most tissues is the mast cell. Therefore, the concentration of histamine is particularly high in tissues that contain large numbers of mast cells (e.g. skin, bronchial mucosa, and intestinal mucosa) [13]. An increased level of histamine within tissue rapidly activates histamine receptors (HRs) on endothelial cells and smooth muscle cells, leading to the development of such symptoms as acute rhinitis, bronchoconstriction, cramping, diarrhea, cutaneous weal and flare responses [14]. Immunological cells, as well as tissue resident cells, express a various set of histamine receptors. Two HR types, H1R and H4R, currently seem to be most important for allergic reactions and inflammatory response development. Histamine $\mathrm{H} 1$ receptors are very widely expressed throughout the body, amongst others in epithelial, vascular, smooth vascular, neuronal, glial, and immune cells [1517]. H1Rs also mediate neuronal excitation; their blockade by the classical antihistamines leads to sedation [18].

The second HR important for allergic and inflammatory reactions, histamine $\mathrm{H} 4$ receptor, is expressed mainly on cells involved in immune/ inflammatory responses. It is present at a high level on hematopoietic cells in bone marrow and peripheral immune cells such as eosinophils, mast cells, dendritic cells, and T cells [6, 19]. While $\mathrm{H} 2$ receptor stimulation increases cyclic AMP and causes feedback inhibition of histamine release from mast cells and basophils, activation of $\mathrm{H}_{3}$ and $\mathrm{H}_{4}$ receptors has the opposite effect by decreasing cellular cyclic AMP [20].

Histamine regulates a number of processes and effects crucial for the development of the inflammatory response - chemotaxis, vascular permeability, pain response - and influences the level of inflammatory mediators including its own production and release [21]. In general, the effect of histamine on a single cell depends on the cell phenotype and affinity of its receptors for histamine. For example, histamine differentially regulates T-helper-1 (Th1) and T-helper-2 (Th2) cells. Th1 cells show predominant histamine $\mathrm{H} 1$ receptor expression - its activation enhances IFN- $\gamma$ (IFN- $\gamma$ ) production and Th1 proliferation [6]. Th2 cells show increased expression of histamine $\mathrm{H} 2$ receptor, its activation suppresses interleukin-4 (IL-4) and IL-10 production, and the suppressive effect of transforming growth factor- $\beta$ (TGF- $\beta$ ) is potentiated as well [22]. H4R is functionally expressed on activated DC and may influence cytokine-induced differentiation of dendritic cells [6]. The DCs are professional antigen-presenting cells in the immune system of mammalians. Their primary function is to process antigen material and present it on the cell surface to the $T$ cells [23]. Activation of H1R and H3R on DCs enhance their antigen-presenting capacity and Th1 priming whereas $\mathrm{H} 2$ receptor activation induces IL-10 production [6]. Histamine inhibits production of proinflammatory cytokines by monocytes IL-1, IL-12, IL-18, and tumor necrosis factor- $\alpha$ (TNF- $\alpha$ ) and enhances production of IL-10. Histamine also affects antibody production by B cells [6].

Histamine is a potent mediator that plays a crucial role in the pathophysiology of several disorders and the development of many disease symptoms. This compound is one of the key mediators responsible for the development of allergic 
rhinitis (AR, hay fever), pruritus, urticaria, atopic dermatitis (AD), allergic conjunctivitis and anaphylaxis [13]. It is also involved in asthma pathophysiology [6]. The essential data on the role of $\mathrm{H}$ and its receptors in some allergic/inflammatory diseases are summarized in Table I [24-34]. Histamine receptors' involvement will be discussed in detail in later sections.

\section{Insufficient therapeutic potential of $\mathrm{H} 1 \mathrm{R}$ and H2R antagonists in some allergic and inflammatory diseases}

Many histamine $\mathrm{H} 1$ receptor antagonists are widely available over the counter and at low price. Although generally still referred to as H1R antagonists, so-called $\mathrm{H} 1$ antihistamines (rarely: H1R blockers) are not receptor antagonists, but are actually inverse agonists that reduce the constitutive activity of the receptor and compete with histamine [16, 35].

Currently, histamine $\mathrm{H} 1$ receptor antagonists continue to play a dominant role in the treatment of allergic disorders (most effective in acute types of allergy that present with symptoms of rhinitis, urticaria, and conjunctivitis; also useful as ancillary treatment in some patients with atopic dermatitis, allergic conjunctivitis, and even asthma, as well as being used unjustly in common cold) $[10,13]$. These well-known applications of H1R antagonists will not be discussed in the present article.

Histamine $\mathrm{H} 2$ antagonists are used mainly in gastrointestinal disorders (e.g. cimetidine, ranitidine, famotidine and nizatidine). However, some $\mathrm{H} 2 \mathrm{R}$ antagonists used as an add-on treatment to $\mathrm{H} 1 \mathrm{R}$ antagonists may be effective in allergic disorders (see below). Nowadays, there are no new H2R antagonists intended to treat allergic and inflammatory disorders. In cases of severe or persistent urticaria refractory to treatment with $\mathrm{H} 1 \mathrm{R}$ antihistamine alone, H2R antagonists can also be used off-label [9, 36].

Randomized controlled studies are necessary to assess whether the addition of antihistamines improves the respiratory and cardiovascular features of anaphylaxis; oral H2- (and, of course, H1-) antihistamines are thus only recommended for the relief of cutaneous symptoms of anaphylaxis, particularly the itching and urticaria [37]. It was found that the concomitant use of $\mathrm{H} 1$ and $\mathrm{H} 2$ antagonists may generate additional benefits over (and above) systemic $\mathrm{H} 1$-antihistamines alone in relieving some cutaneous symptoms in persons experiencing acute allergic reactions during anaphylactic reaction [38, 39]. However, the routine prophylactic use of systemic premedication with H1R and/or H2R antagonists cannot be recommended in unselected people undergoing proce- dures with iodinated radiocontrast media as they do not prevent life-threatening reactions [40]. There is a lack of data supporting the use of such premedication in patients with a previous reaction to another allergen [41].

Even though classical antihistamine drugs (i.e. H1R antagonists) are effective, they do not eliminate all histamine-mediated symptoms and signs; for example in allergic rhinitis the relief of some symptoms, such as congestion, is not complete [13]. Moreover, in some conditions where a histamine-dependent mechanism is responsible for the pathophysiology and symptoms only in part, such as asthma, H1R antagonists show weak activity and are used only as supplementary treatment [13]. Although there is some evidence for the role of histamine in the pathophysiology of asthma, neither $\mathrm{H} 1$ nor $\mathrm{H} 2$ antihistamines have been shown to be substantially effective for this disorder (limited efficacy, not used as sole therapy) [13]. H1R antagonists given as monotherapy proved to be ineffective in asthma [6].

Similarly, even though H1R antagonists are commonly prescribed by physicians as an adjunctive treatment along with topical corticosteroids and calcineurin inhibitors in treating pruritus in atopic dermatitis, clinical data show that these drugs have unsatisfactory effectiveness or are ineffective [42-44]. Pruritus is a histamine-dependent process, as injection of histamine into the human skin causes the sensation of itching [45]. $\mathrm{H} 1$ antihistamines are efficacious in reducing itching in some conditions such as acute urticaria, allergic rhinitis or insect bite reaction. However, the itch occurring in some chronic pruritic diseases, especially AD, wherein pruritus is the most disabling symptom [46], is not well controlled by these drugs (nor antihistamines targeting the $\mathrm{H} 2$ receptors).

\section{Histamine $\mathrm{H} 2, \mathrm{H} 3$ and $\mathrm{H} 4$ receptors and their properties}

It is now believed that histamine $\mathrm{H} 3$ and $\mathrm{H} 4$ receptors are responsible for many properties of histamine [6]. In recent years, a growing body of evidence has indicated that ligands, especially antagonists, of H4Rs (and, to a lesser extent H3Rs and even H2Rs) could play an important role in treatment of some allergic and inflammatory conditions. Therefore, distribution of these receptors and their pharmacological properties are presented below.

\section{Distribution of $\mathrm{H} 2$ receptors}

Strong expression of $\mathrm{H} 2$ receptors in the stomach and brain was demonstrated a long time ago [47]. The $\mathrm{H} 2$ receptor is also expressed in smooth 
Table I. The role of histamine and its receptors in some allergic and inflammatory diseases

\begin{tabular}{|c|c|c|c|}
\hline $\begin{array}{l}\text { Condition/ } \\
\text { symptom }\end{array}$ & Signs/symptoms & Histamine role in the condition & $\begin{array}{l}\text { Histamine receptor(s) } \\
\text { involvement }\end{array}$ \\
\hline Allergic rhinitis & $\begin{array}{l}\text { Pruritus, sneezing, } \\
\text { rhinorrhea, nasal } \\
\text { congestion }\end{array}$ & $\begin{array}{l}\text { Major role in early symptoms of AR; } \\
\text { degranulation of MCs with } \mathrm{H} \text { release } \\
\text { determines the occurrence } \\
\text { of symptoms [6] }\end{array}$ & $\begin{array}{l}\text { H1R, H3R, H4R. } \\
\text { H1Rs are responsible for } \\
\text { most of the AR symptoms } \\
\text { [13]. H1RA are frequently } \\
\text { used in AR treatment, } \\
\text { but present minor anti- } \\
\text { inflammatory activity [24]. } \\
\text { Recent research indicates } \\
\text { that additional beneficial } \\
\text { effects of } \mathrm{H} \text { are mediated } \\
\text { by H3Rs and H4Rs [6] }\end{array}$ \\
\hline $\begin{array}{l}\text { Atopic } \\
\text { dermatitis/ } \\
\text { pruritus }\end{array}$ & Itch & $\begin{array}{l}\mathrm{H} \text { indirectly induces production of } \\
\mathrm{IL}-31 \text {, reduces the expression of } \\
\text { Sema3 } \mathrm{A}^{* *}[25-28] ; \mathrm{H} \text { also acts directly } \\
\text { via } \mathrm{H} 1 \mathrm{R} \text { and } \mathrm{H} 4 \mathrm{R} \text { located on sensory } \\
\text { neurons and results in itching }[27,29]\end{array}$ & $\mathrm{H} 1 \mathrm{R}, \mathrm{H} 3 \mathrm{R}, \mathrm{H} 4 \mathrm{R}$ \\
\hline Urticaria & $\begin{array}{l}\text { Blisters, itching and } \\
\text { angioedema as a result } \\
\text { of vasodilatation/fluid } \\
\text { leakage [10]; pruritus and } \\
\text { reflex erythema following } \\
\text { activation of sensory } \\
\text { nerves }\end{array}$ & $\begin{array}{l}\text { Release of large amounts of } \mathrm{H} \text { from } \\
\text { MCs; also activation of sensory nerves }\end{array}$ & $\begin{array}{c}\text { Probably all the four types } \\
\text { of HRs, but effectiveness } \\
\text { of H2RA and H3RA is } \\
\text { uncertain }\end{array}$ \\
\hline $\begin{array}{l}\text { Allergic } \\
\text { conjunctivitis }\end{array}$ & $\begin{array}{l}\text { Ocular itching, eyelid } \\
\text { swelling, tearing, } \\
\text { watery discharge, } \\
\text { photophobia, and foreign } \\
\text { body sensation with } \\
\text { pain. Accumulation of } \\
\text { inflammatory cells in } \\
\text { the conjunctival mucosa } \\
\text { occurs }\end{array}$ & $\begin{array}{l}\text { Liberation of large quantities of } \\
\mathrm{H} \text { from conjunctival MCs after } \\
\text { stimulation with an allergen [6]. } \\
\text { MC-derived mediators activate } \\
\text { vascular endothelial cells which in } \\
\text { turn increase expression of adhesion } \\
\text { molecules***, secretion of RANTES } \\
\text { chemotactic chemokine, monocyte } \\
\text { chemoattractant protein, IL-8, eotaxin } \\
\text { and macrophage inflammatory } \\
\text { protein-1 } \alpha \text { [30-32] }\end{array}$ & $\mathrm{H} 1 \mathrm{R}, \mathrm{H} 2 \mathrm{R}, \mathrm{H} 4 \mathrm{R}$ \\
\hline Anaphylaxis & $\begin{array}{l}\text { Increased vascular } \\
\text { permeability, smooth } \\
\text { muscle contractions, } \\
\text { urticaria, hypotension, } \\
\text { dyspnea, diarrhea, } \\
\text { abdominal cramps; taken } \\
\text { together these processes } \\
\text { leads to anaphylaxis [13] }\end{array}$ & $\begin{array}{l}\text { Binding of antigens to IgE receptor } \\
\text { molecules located on immunological } \\
\text { cells leads to their activation and } \\
\mathrm{H} \text { and other mediators released } \\
\text { from immunological cells causes } \\
\text { anaphylaxis. An experimental study } \\
\text { in the mouse systemic anaphylaxis } \\
\text { model (HDC-KO) revealed that } \mathrm{H} \text { is } \\
\text { responsible for control of respiratory } \\
\text { frequency, expiratory time and body } \\
\text { temperature [33] }\end{array}$ & $\begin{array}{l}\mathrm{H} 1 \mathrm{R}, \mathrm{H} 2 \mathrm{R} \text { (cutaneous } \\
\text { symptoms), H4R }\end{array}$ \\
\hline Asthma & & $\begin{array}{l}\text { Large amounts of } \mathrm{H} \text { released by } \\
\text { MCs stimulate other cells involved } \\
\text { in the attack of asthma [6]. The DC } \\
\text { are responsible for the activation of } \\
\text { CD4+ cells. Th2 lymphocytes produce } \\
\text { proinflammatory cytokines, e.g. IL-4, } \\
\text { IL-5, and IL-13 during asthma attack }\end{array}$ & $\begin{array}{l}\text { H4R and (to a lesser } \\
\text { extent) H1R and H2R. } \\
\text { H4RA decrease cytokine } \\
\text { and chemokine } \\
\text { production by DC and } \\
\text { directly limit their ability } \\
\text { to induce Th2 responses } \\
\text { [34]. H4R is expressed } \\
\text { on eosinophils and } \\
\text { H is involved in their } \\
\text { accumulation in the } \\
\text { airways after allergic } \\
\text { challenge [6] }\end{array}$ \\
\hline
\end{tabular}

$A R$ - allergic rhinitis, CD4+ - cluster of differentiation 4 (cells), DC - dendritic cells, $H$ - histamine, H1RA - H1R antagonists, H1Rs - H1 receptors, H2RA - H2R antagonists, H3RA - H3R antagonists, H4RA - H4R antagonists, HDC-KO - histidine decarboxylase knockout, IgE - immunoglobulin E, IL-4 - interleukin-4, IL-5 - interleukin-5, IL-8 - interleukin-8, IL-13-interleukin-13, IL-31 - interleukin-31, MC(S) mast cell(s), RANTES - regulated on activation, normal T cell expressed and secreted, also known as chemokine ligand or CCL5, Sema3A - semaphorin 3A. *Pruritus is a major symptom of allergic skin diseases such as $A D$. ** Semaphorin $3 A$ is a guidance molecule of nerve fibers, regulator of the motility of dorsal root ganglia (DRG) growth cones as well as axonal morphogenesis [25, 26]; it inhibits extension of C-fibers in the upper layer of the epidermis and increases the level of nerve growth factor (NGF) [27, 28]. ***Intercellular adhesion molecule (ICAM) and vascular cell adhesion molecule (VCAM). 
muscle cells, chondrocytes, endothelial and epithelial cells, neutrophils, basophils, eosinophils, granulocytes (polymorphonuclear leukocytes - PMN/ $\mathrm{PML}$ ), monocytes, macrophages, DC, T cells (including $\gamma \delta \mathrm{T}$, T helper 1,2$)$, and B cells $[12,14,22]$. Activation of $\mathrm{H} 2 \mathrm{Rs}$ also excites certain neurons [48].

\section{Distribution of $\mathrm{H} 3$ receptors}

$\mathrm{H} 3$ receptor plays important roles in multiple functions in the CNS [6]. It was shown that H3R is expressed mainly in the CNS and affects cognitive functions such as memory; disturbance of its expression may be indirectly related to the development of Alzheimer's disease [6, 49, 50]. Stimulation of H3R promotes sleep [13]. H3Rs are inhibitory autoreceptors as well as heteroreceptors with complex function. Histamine production and release in the brain is subject to feedback regulation involving $\mathrm{H} 3$ autoreceptors. A Large number of nonhistaminergic neurons also carry H3R; therefore a whole range of interactions between different neurotransmitter systems is possible [51].

High expression of the $\mathrm{H} 3$ receptor was demonstrated in the brain; it is widely distributed in very important areas of the human brain, e.g., cerebral cortex, caudate putamen, thalamus, ventromedial nucleus of the hypothalamus, and several aminergic projection systems (including histaminergic tuberomammillary nucleus - TMN neurons) and the noradrenergic neurons of the locus coeruleus [52]. In the human basal ganglia, $\mathrm{H} 3$ receptor was detected in the putamen, frontal cortex, globus pallidus externum, and globus pallidus internum [53]. Widespread H3R expression was also observed in rats during embryonic development in the medulla oblongata and spinal cord, as well as in brown fat [54], spinal ganglia, and in the periphery - in salivary glands, respiratory epithelium, gastric and intestinal mucosa, skin, thymus, liver, heart, and kidney [55], suggesting that H3R-mediated functions may extend beyond the CNS during development. In adult rats, the $\mathrm{H} 3$ receptor was found in stomach (extracellular loop (ECL) cells, also expressing histidine decarboxylase (HDC), a key enzyme in histamine synthesis) [56]. In mouse DRG, the $\mathrm{H} 3$ receptor is localized in medium-sized and large cells, which also expressed calcitonin gene-related peptide (CGRP). This localization may suggest that fibers containing $\mathrm{H} 3 \mathrm{R}$ are involved in high-threshold mechanical nociception [6]. Sympathetic neurotransmitter release is regulated by H3Rs in some human and animal body structures [6], e.g. human heart [57] and dog kidney [58]. Regulation involving H3Rs also covers neuropeptide (tachykinins or CGRP) release from sensory $C$ fibers in airways [59], skin [60], heart [57], and meninges [61].

\section{Distribution of $\mathrm{H} 4$ receptors}

$\mathrm{H} 4 \mathrm{R}$ receptors occur predominantly in the peripheral immune cells, as mast cells, eosinophils, neutrophils, dendritic cells, Langerhans cells, natural killer (NK) cells, monocytes, T cells (including $\gamma \delta \mathrm{T}$, Thelper 1, 2, Th17, and CD8 cells), keratinocytes, inflammatory dendritic epidermal cells, fibroblasts as well as (without any functional data at this stage) epithelial cells and basophils [6, 12]. Expression of H4R in nasal polyp tissue taken from patients with chronic rhinosinusitis is significantly higher than in normal nasal mucosa [62]. One recent study questions the presence of $\mathrm{H} 4 \mathrm{R}$ in human monocytes [63]. The issue of the presence and role of $H 4 R$ in brain nervous tissue has not been definitively explained [48], but there is evidence of H4R expression in non-neuronal cells in the brain [64].

\section{Properties and features of $\mathrm{H} 3$ receptors and their ligands potentially relevant to anti-allergic and anti-inflammatory drug development - data from in vitro/animal studies}

Compared to $\mathrm{H} 4$ receptors, there are relatively limited literature data on $\mathrm{H} 3$ receptors allowing anticipation of potential anti-allergic or anti-inflammatory drug development. The presence of $\mathrm{H} 3$ receptors was demonstrated in the epidermal layer of the human nasal mucous membrane (mainly around submucosal gland cells) [65]. Studies by Yokota et al. show the similar inhibition of nasal symptoms of allergic rhinitis by cetirizine and $\mathrm{H} 3$ receptor agonists (Sch 50971 and imetit) in mouse models [66] (chemical names of all new ligands of H3Rs and H4Rs are shown in Tables II-IV). Also, co-administration of Sch 50971 or imetit and an H1R antagonist, cetirizine, produced synergism - an inhibitory effect on nasal symptoms occurred at doses of substances that had no effect when used separately [66]. These results indicate that H3Rs are involved in the etiology of nasal allergy, and their stimulation may be useful as a novel therapeutic approach in nasal allergy. However, observations from a preclinical model of nasal congestion (NC) showed that H3Rs along with $\mathrm{H} 1 \mathrm{Rs}$ participated in the histamine-induced NC and demonstrated the sense of simultaneously blocking both $\mathrm{H} 1$ and $\mathrm{H} 3$ receptors in conditions with NC $[67,68]$. Also, compound SCH-79687 is a highly potent $\mathrm{H} 3 \mathrm{R}$ antagonist that reduced congestion in animal models of AR when co-administered with a H1R antagonist [69]. This supports the hypothesis that the efficacy of H3R antagonists is related to peripherally mediated release of norepinephrine from nasal mucosal $\mathrm{H} 3$ receptors, because $\mathrm{SCH}-79687$ virtually does not penetrate the brain [70]. 
Moreover, histamine displayed a significant role in both early-phase swelling via $\mathrm{H} 1$ receptors and late-phase swelling via $\mathrm{H} 3 / \mathrm{H} 4$ receptors in a 12-O-tetradecanoylphorbol 13-acetate (TPA)-modified allergic dermatitis model in mouse earlobes established by Hirasawa and Ohuchi [71] for analyzing the role of histamine using specific HR antagonists. Earlier Hirasawa et al. reached a similar conclusion [72]. The effects observed suggest a possibility of effective H3R ligands' use in allergic rhinitis and possibly allergic dermatitis.

Abovementioned potential uses of H3R ligands require confirmation in clinical studies.

Table II. Names and type of action of new selective ligands of H3 receptor mentioned in the review, in alphabetical order

\begin{tabular}{|lrcc|}
\hline Ligand name & Chemical name of ligand & Type of action \\
\hline JNJ39220675 & (4-cyclobutyl-1,4-diazepan-1-yl)(6-(4-fluorophenoxy)pyridin-3-yl)methanone & Antagonist \\
\hline PF-03654746 & trans-N-ethyl-3-fluoro-3-[3-fluoro-4-(pyrrolidinylmethyl)phenyl] & cyclobutanecarboxamide & Antagonist \\
\hline PF-03654764 & trans-3-fluoro-3-[3-fluoro-4-(pyrrolidin-1-ylmethyl)phenyl]-N-(2-methylpropyl) & Antagonist \\
& cyclobutanecarboxamide & Agonist \\
\hline Sch 50971 & (+)-trans-4-(4(R)-methyl-3(R)-pyrolidinyl)-1H-imidazole dihydrochloride & Antagonist \\
\hline SCH-79687 & -(3,5-dichlorophenyl)-N'-[[4-(1H-imidazol-4-ylmethyl)phenyl]-methyl]-urea & &
\end{tabular}

Table III. Names and type of action of new dual ligands of $\mathrm{H}$ receptors mentioned in the review, in alphabetical order

\begin{tabular}{|c|c|c|}
\hline Ligand name & Chemical name of ligand & $\begin{array}{l}\text { Type of action } \\
\text { and target } \\
\text { receptors }\end{array}$ \\
\hline GSK1004723 & $\begin{array}{l}\text { 4-[(4-chlorophenyl)methyl]-2-(\{(2R)-1-[4-(4-\{[3-(hexahydro-1H-azepin-1-yl)propyl] } \\
\text { oxy }\} \text { phenyl)butyl]-2-pyrrolidinyl }\} \text { methyl)-1(2H)-phthalazinone }\end{array}$ & $\begin{array}{l}\mathrm{H} 1 \mathrm{R} / \mathrm{H} 3 \mathrm{R} \\
\text { antagonist }\end{array}$ \\
\hline GSK835726 & $\begin{array}{l}\text { 9H-fluoren-9-ylmethyl N-[(2S)-1-[[(2S)-6-amino-1-[(4-methyl-2-oxochromen-7- } \\
\text { yl)amino]-1-oxohexan-2-yl]amino]-3-cyclohexyl-1-oxopropan-2-yl]carbamate; } \\
\text { 2,2,2-trifluoroacetic acid }\end{array}$ & $\begin{array}{l}\mathrm{H} 1 \mathrm{R} / \mathrm{H} 3 \mathrm{R} \\
\text { antagonist }\end{array}$ \\
\hline
\end{tabular}

Table IV. Names and type of action of new selective ligands of $\mathrm{H} 4$ receptor mentioned in the review, in alphabetical order

\begin{tabular}{|c|c|c|}
\hline Ligand name & Chemical name of ligand & Type of action \\
\hline A-940894 & 4-piperazin-1-yl-6,7-dihydro-5H-benzo[6,7]cyclohepta[1,2-d]pyrimidin-2-ylamine & Antagonist \\
\hline A-943931 & $\begin{array}{l}\text { 4-[(3R)-3-aminopyrrolidin-1-yl]-6,7-dihydro-5H-benzo[1,2]cyclohepta[3,4-b] } \\
\text { pyrimidin-2-amine }\end{array}$ & Antagonist \\
\hline A-987306 & $\begin{array}{c}\text { cis-4-(piperazin-1-yl)-5,6,7a,8,9,10,11,11a-octahydrobenzofuro[2,3-h]quinazolin- } \\
\text { 2-amine }\end{array}$ & Antagonist \\
\hline INCB38579 & $\begin{array}{l}\text { 1-(7-(2-amino-6-(4-methylpiperazin-1-yl) pyrimidin-4-yl)-3, 4-dihdroisoquinolin- } \\
\text { 2(1H)-yl)-2-cyclopentylethanone }\end{array}$ & Antagonist \\
\hline $\begin{array}{l}\text { JNJ10191584 } \\
=\text { VUF6002 }\end{array}$ & 1-[(5-chloro-1H-benzimidazol-2-yl)carbonyl]-4-methylpiperazine & Antagonist \\
\hline JNJ28307474 & $\begin{array}{c}\text { (5-fluoro-4-methyl-2- }\{5 \text {-methyl-2-[4-(l-methyl-piperidin-4-yl)-butoxy]-pyridin- } \\
\text { 4yl\}-lH-benzoimidazole) }\end{array}$ & Antagonist \\
\hline JNJ28610244 & (Z)-(5-methyl-1H-indol-2-yl)-(1-methyl-piperidin-4-yl)-methanone oxime & Agonist \\
\hline $\begin{array}{l}\text { JNJ38518168 } \\
\text { (toreforant) }\end{array}$ & $\begin{array}{l}\text { 5-(4,6-dimethyl-1H-benzimidazol-2-yl)-4-methyl-N-[3-(1-methylpiperidin-4-yl) } \\
\text { propyl]pyrimidin-2-amine)] }\end{array}$ & Antagonist \\
\hline JNJ39758979 & (R)-4-(3-amino-pyrrolidin-1-yl)-6-isopropyl-pyrimidin-2-ylamine & Antagonist \\
\hline JNJ7777120 & 1-[(5-chloro-1H-indol-2-yl)carbonyl]-4-methylpiperazine & Antagonist \\
\hline KD1157 & The chemical structure of this compound has not been unveiled yet & Antagonist \\
\hline UR63325 & $\begin{array}{l}\text { 9-[3-(methylamino)azetidin-1-yl]-7-oxa-10,12-diazatricyclo[6.4.0.0(2,6)]dodeca- } \\
\qquad 1(12), 2(6), 8,10 \text {-tetraen-11-amine }\end{array}$ & Antagonist \\
\hline $\begin{array}{l}\text { ZPL3893787 } \\
(\text { PF-3893787) }\end{array}$ & $\begin{array}{c}\text { 4-N-(cyclopropylmethyl)-6-[(3R)-3-(methylamino)pyrrolidin-1-yl]pyrimidine-2,4- } \\
\text { diamine }]\end{array}$ & Antagonist \\
\hline
\end{tabular}


Properties and features of $\mathrm{H} 4$ receptors and their ligands potentially relevant to anti-allergic and anti-inflammatory drug development - data from in vitro/animal studies

\section{Properties and features of $\mathrm{H} 4$ receptors}

Numerous studies have shown a regulatory effect of H4R on the influx and chemotaxis of inflammatory cells [73-76] and an inhibitory effect of H4R antagonists on these processes. H4Rs on eosinophils mediate histamine-induced eosinophil chemotaxis, a vital element of the inflammatory response in allergic rhinitis [77] and asthma [78], as well as the calcium response (increase in intracellular calcium) in eosinophils, and consistently selective H4R antagonists (JNJ7777120, A-940894 and INCB38579) hindered histamine-induced chemotaxis and calcium responses [79-82]. Chemotaxis of eosinophils evaluated indirectly by measuring the change of blood cell shape related to actin reorganization that precedes chemotaxis [83] also was blocked by H4R selective antagonists and induced by histamine and selective $\mathrm{H} 4 \mathrm{R}$ agonists (e.g. 4-methylhistamine) [79, 80, 84-86].

In the case of mast cells, crucially important for inflammation and allergy, H4Rs seems to have an indirect modulating effect on degranulation by inducing upregulation of high-affinity IgE receptors (Fc epsilon RI - FcERI) [87]. Similar to eosinophils, the action of histamine (and H4R agonists) at $\mathrm{H} 4$ receptors can produce a calcium response in mast cells as well as its chemotaxis. Histamine-induced increases in intracellular calcium can be blocked by JNJ7777120 [88]. The chemotactic effect can be blocked by H4R antagonists, but not by the antagonists of other histamine receptors $[85,88$, 89]. As for data on eosinophils, changes in mast cell shape caused by chemotaxis occur and are blocked by H4R antagonists [81]. In turn, the H4R agonist 4-methylhistamine-induced chemotaxis was blocked by JNJ7777120 [84].

Moreover, the stimulation of H4R increases production of inflammatory mediators by mast cells. In mouse mast cells induction of IL- 6 production and potentiation of the IL- 6 production driven by LPS stimulation by histamine and the H4R agonist JNJ28610244 were blocked by H4R antagonists JNJ7777120 and JNJ28307474 [90]. In human mast cells H4R mediates the release of cytokines, leukotrienes, and chemokines [91].

Blockade of H4R also resulted in decreased proinflammatory cytokine production in intestinal [92] and airway tissues [93].

Asthma is a condition typically associated with eosinophils and mast cells [94-96]. Because of the localization and function of $\mathrm{H}_{4}$ receptors, $\mathrm{H} 4 \mathrm{Rs}$ may be involved in asthma pathophysiology [24, 97], for example by diminishing airway inflammation and dysfunction via modulation of Th2 cytokine function [93]. The histamine $\mathrm{H} 4$ receptor mediates allergic airway inflammation by regulating the activation of CD4+ T cells in mice [34]. Moreover, H4R-deficient mice and mice treated with H4R antagonists JNJ7777120 or JNJ10191584 (or VUF6002) exhibited decreased allergic lung inflammation, with decreases in infiltrating lung eosinophils/lymphocytes and Th2 responses, reduced inflammatory cytokines, as well as decreased antigen specific IgE and IgG1 levels after allergen challenge [34]. In in vitro studies blockade of the H4R on dendritic cells caused reduction in cytokine and chemokine production and limited their ability to induce Th2 responses in T cells [34]. Administration of H4R antagonists (JNJ7777120, JNJ39758979 or JNJ10191584) during allergen challenge also reduced the eosinophilia in animal asthma models [34, 85, 93, 98, 99]. Unexpectedly it turned out that mast cells were not needed for the $\mathrm{H} 4 \mathrm{R}$ response in the mouse asthma models; in mice lacking mast cells inhibition of lung inflammatory cytokines levels and eosinophilia after H4R antagonists JNJ7777120 or JNJ10191584 was still present [34]. This suggests that T cells may be the main factor involved in the $\mathrm{H} 4 \mathrm{R}$ response not in the airways only. Probably the $\mathrm{H} 4$ receptor plays a role in the priming and activation of T cells [45].

Reduction in Th2 cytokines has been shown in the skin after treatment with an H4R antagonist; therefore the activation of T cells may also be considered as the primary mechanism in the models of atopic dermatitis [100-103].

Several mechanisms for the H4R effect on $T$ cells exist. Administration of $\mathrm{H} 4 \mathrm{R}$ antagonists reduces the number of $T$ cells at the site of inflammation in dermatitis and asthma animal models $[93,104]$. The decrease in $T$ cell number may be a result of inhibition of chemokine production [93, 100] or the immediate chemoattractive effect of histamine on T cells $[105,106]$. Expression of H4R has been shown on human Th2 cells and agonists of H4R enhanced the expression of IL-31 [107]. Indirect effects on T cells also exist; H4R is involved in dendritic cell function and this way drives the response in asthma [45].

The DCs are basic antigen-presenting cells [108], important also for anaphylactic reactions. $\mathrm{H} 4 \mathrm{R}$ in dendritic cells mediates migration of these cells to the site of interaction with T cells; migration of antigen-positive DCs from the skin to the lymph node was reduced under the influence of H4R antagonist JNJ7777120 administration [100]. Effects on DC migration may be a result of direct $\mathrm{H} 4 \mathrm{R}$ mediation via chemoattractive action of histamine [109-113] or indirect reduction of chemo- 
kine production [93, 100]. H4R modulates cytokine/chemokine production by dendritic cells that may lead to defective T cell activation [34, 109, 112-115]. H4R may also influence maturation/ activation of dendritic cells [45]. The DCs can be activated by endogenous danger signals involving toll-like receptors (TLRs). The process of DC activation in vitro with TLR ligands, generally leading to the production of cytokines and chemokines, can be modulated by H4R antagonists [34, 109, 112-115]. It was recently established that combined blockade of the histamine $\mathrm{H} 1$ (loratadine) and $\mathrm{H} 4$ (JNJ7777120) receptor suppresses peanut-induced intestinal anaphylaxis by regulating dendritic cell function in a mouse model (effects mediated through the limitation of mesenteric lymph node and intestinal DC accumulation and function) [116].

Among inflammatory conditions, especially autoimmune disease, rheumatoid arthritis (RA) is considered as partially driven by $T$ cell responses [45]. After administration of the H4R antagonist JNJ28307474 mice were protected from RA in two arthritis models (collagen-induced (CIAM) and collagen antibody-induced (CAIAM)), as were H4R-deficient mice [117]. Another selective H4R antagonist, JNJ39758979, also mitigated RA in the CIAM [118]. Administration of the H4R antagonist in CIAM reduced the production of IL- 17 from lymphocytes and the number of Th17 cells (IL-17 positive CD4 cells) in the inguinal lymph node, but did not influence the IFN- $\gamma$ production $[34,117]$. Human and mouse Th17 cells displayed expression of H4R [117, 119]. Reduction of IL-17 production by $\mathrm{H} 4 \mathrm{R}$ antagonists has been reported in models of asthma and dermatitis; also Th17 cell differentiation was blocked under the influence of these compounds in vitro [34, 100,117]. The observed effects on T cells have been direct or indirect; in the CAIAM adoptive transfer of splenic CD11c+ cells (wild-type dendritic cells) restored disease in H4R-deficient animals, which indicates that the $\mathrm{H} 4 \mathrm{R}$ on antigen presenting cells was decisive for RA activity [117]. Production of IL-17 in isolated human Th17 cells was reduced by the H4R antagonist JNJ7777120 and enhanced by an H4R agonist, suggesting a direct effect of H4R on Th17 cells [119].

Among conditions studied, an exception is experimental autoimmune encephalomyelitis - in this autoimmune condition treatment with an $\mathrm{H} 4 \mathrm{R}$ antagonist (or lack of H4Rs) significantly worsens disease in a mouse model $[75,120]$.

Pruritus. A scratching response in mice induced by injection of histamine into the skin was inhibited by treatment with $\mathrm{H} 4 \mathrm{R}$ antagonists [80, 118, 121-123], suggesting that $H 4 R$ could be responsible for pruritic responses not driven by H1R. The same conclusion can be drawn with regard to the induction of scratching after injection of $\mathrm{H} 4 \mathrm{R}$ agonists in mice, inhibition of this effect with $\mathrm{H} 4 \mathrm{R}$ antagonists or in H4R-deficient mice [86, 122, 124-126] and to the reduction of histamine-induced scratching in H4R-deficient mice [122]. H4R antagonists inhibited scratching in animal models of dermatitis [100,103,123,127, 128] and relieved scratching in mice induced by substance $P$ [123] and haptens; in the latter case $\mathrm{H} 4$ receptor antagonism reduces scratching behavior but not inflammation [127].

The effects on mast cells, eosinophils, and $T$ cells described above indicates a possibility of H4R ligands' use in such inflammatory conditions/symptoms as atopic dermatitis, asthma, allergic rhinitis, rheumatoid arthritis, pruritus or neuropathic pain in humans.

\section{Activity of H4R ligands in animals}

Preclinical evidence pointed to the key role of H4R in several histamine-related physiological and pathophysiological processes including airway inflammation, dermal inflammation, pruritus, ocular inflammation, arthritis, systemic lupus erythematosus, Sjogren's syndrome, multiple sclerosis, gastric ulcer, cancer, and pain [45, 129]. Reduction of neutrophil influx in a mouse peritonitis model was observed after pretreatment with JNJ7777120, providing the first evidence that H4R antagonists could have anti-inflammatory properties [88]. Other early research also showed that JNJ7777120 and its congener, JNJ10191584, are also effective in a rat colitis model [92]. Along with other H4R antagonists, such as JNJ10191584, JNJ39758979, JNJ28307474, A-943931 and A-987306, JNJ7777120 has demonstrated activity in models of asthma (JNJ7777120 [93, 98, 130]; JNJ7777120 and JNJ10191584 [34]; JNJ39758979 [85]), dermatitis (JNJ7777120 [101103, 127, 128]; JNJ77777120 and JNJ28307474 [131]; JNJ28307474 [100]; JNJ39758979 [85]), pruritus (see below), arthritis (JNJ28307474 [117]) and pain (JNJ7777120 [76], A-943931 [124], A-987306 [125]). JNJ7777120 effects in models of dermatitis, asthma, arthritis, peritonitis, and pain were consistent with those obtained using other selective H4R ligands (especially antagonists) and effects in H4R-deficient animals [34, 75, 100, 117, 122]. The H4R antagonist JNJ7777120 also exerts anti-inflammatory and antifibrotic effects in bleomycin-induced lung inflammation in mice; the antifibrotic effect of JNJ7777120 is manifested by a reduction of the tissue concentration of TGF- $\beta$, collagen deposition, and smooth muscle layer thickness [132].

The importance of histamine for development of pruritus has been known for years. Recently 
studies using selective H4R ligands in animal models of pruritus revealed a role for H4R in mediating chronic pruritus associated with conditions such as atopic dermatitis [27, 45, 103]. Antagonists of H4R (JNJ7777120, JNJ39758979, INCB38579 and others) reduced pruritus in a number of animal studies [80, 100,103, 118, 122-128] as well as itching sensation in different conditions in human patients [133-136]. Blockade of $\mathrm{H} 4$ receptors by the compound JNJ7777120 was more efficient than H1R inhibition in a mouse model of pruritus [122]. Moreover, it was shown in two mouse models of allergen-mediated pruritus that simultaneous application of the H4R antagonist JNJ7777120 and $\mathrm{H} 1 \mathrm{R}$ antagonist cetirizine reduced scratching bouts by up to $90 \%$ [137].

Alcaftadine, a topical ophthalmic drug indicated for the prevention of itching associated with allergic conjunctivitis, is a potent $H 1 R$ and $H 2 R$ antagonist (in fact, inverse agonist) with weak inverse agonistic activity also towards H4R [138, 139]; this drug acts as a functional antagonist of $\mathrm{H} 4$ receptor signaling [140]. Preclinical data suggest that the combination of H4R and H1R antagonists may be more effective against pruritus than an H1R antagonist alone [100, 103, 122, 127, 141]. Probably administration of H1R/H4R antagonists or co-administration of H1R and H4R antagonists will be effective also in humans.

In comparison to $\mathrm{H} 1 \mathrm{R}$ antagonists, treatment with H4R ligands bring better results in itching, possibly caused by the additional analgesic component; a role for the $\mathrm{H} 4$ receptor in nociception was suggested recently. The $\mathrm{H} 4 \mathrm{R}$ antagonist JNJ7777120 as well as its benzimidazole analog VUF6002 (JNJ10191584) had proven efficacy in a rat model of carrageenan-induced thermal hyperalgesia, increasing paw withdrawal latency [142]. JNJ77777120 was as efficacious as diclofenac (a nonsteroidal anti-inflammatory drug - NSAiD) in the same model [76]. Similar effects have also been noted with the other $\mathrm{H} 4$ receptor antagonists A-943931 and A-987306 in a rat carrageenan model [124, 125, 143]. Additionally, the $\mathrm{H} 4$ receptor antagonist A-943931 was also effective in a spinal nerve neuropathic pain ligation model [143]. An antinociceptive effect of JNJ7777120 occurred also in a subchronic inflammatory pain model induced by complete Freund's adjuvant and in a skin incision model of postoperative pain-evoking mechanical allodynia [76]. In the latter case, the maximal effect was similar to that of morphine. The same compound in a model of osteoarthritis joint pain (intra-articular injection of sodium monoiodoacetate, pain assessed by the hindlimb grip force) improved the grip force by $47 \%$ compared with a $62 \%$ improvement with celecoxib [76].
H4R antagonists have also proven to be efficacious in models of neuropathic pain. JNJ7777120 showed an effect better than that observed with gabapentin in a rat model of pain induced by chronic constriction of the sciatic or spinal nerve; its effect was maintained for 8 days, which indicates that no tolerance develops [76]. Some 2,4-diamino-5,6-disubstituted pyrimidines antagonizing histamine at $\mathrm{H} 4 \mathrm{R}$ have also shown activity in this model [124].

The mechanisms of presented antinociceptive effects are not clear, but H4Rs in the spinal cord, dorsal root ganglion, and brain may be involved [144]. Moreover, some H4R antagonists may also act as indirect cyclooxygenase inhibitors (suppression of histamine-dependent increasing in COX-2 expression by JNJ7777120 was observed) [145].

The anti-inflammatory effect of the selective H4R antagonist JNJ7777120 was demonstrated in a mouse model of allergic rhinitis. Mice that were sensitized to ovalbumin exhibited a dose-dependent decrease in allergic rhinitis symptoms, such as sneezing and rubbing, after administration of the drug [146]. JNJ7777120 also decreased IgE concentration and increased IFN- $\gamma$ level in an allergic rhinitis model in mice and rats [146, 147], including on repeated oral administration [146]. It was shown that administration of H4R antagonists A-940894 and JNJ7777120 inhibited chemotaxis and influx of immune cells, two processes also important in AR [62, 73, 81].

$\mathrm{H} 4 \mathrm{R}$ may be an attractive pharmacological target also in the treatment of asthma [6]. Only recently studies using selective ligands in animal models of asthma showed a role for H4R in mediating lung function and inflammation [34, $45,93,130,148]$. The expression of H4R on immune cell types known to be involved in asthma (e.g., eosinophils, mast cells, dendritic cells, and $T$ lymphocytes), together with the fact that $H 4 R$ are involved in inflammatory processes, including cytokine production and chemotaxis, supports the idea of use of H4R antagonists in asthma. It was shown that blockade of $\mathrm{H} 4$ receptor leads to reduction of, characteristic for asthma, cytokine production by Th2: IL-4 (by 86\%), IL-5 (95\%), IL-13 (67\%), IL-6 (58\%) and IL-17A (by 92\%) [93, 101, 146]. H4R ligands do not directly influence $T$ cell proliferation and viability [34].

The potential clinical efficacy of H4R ligands needs to be confirmed in relevant clinical trials.

\section{Potential drugs targeting $\mathrm{H} 3$ or $\mathrm{H} 4$ receptors in humans}

In the last 20 years, an extensive search for histamine activity that did not appear to be mediated by the H1Rs and H2Rs was undertaken. From numerous conditions, for H3Rs allergic rhinitis 
[149] and for H4Rs asthma and pruritus [45] appeared as areas of particular interest among immunological and inflammatory diseases. However, none of the H3R and H4R antagonists has yet to be introduced into therapy for the these disorders. There seem to be no reports yet suggesting that the possibility of H2R ligands' use as monotherapy in allergic and inflammatory disorders is real.

\section{H3R ligands}

Until recently, the only registered drug blocking H3R was betahistine, which is used in Ménière's disease, although this compound is also a weak $\mathrm{H} 1$ receptor agonist [150, 151], and, from March 31, 2016 pitolisant (under the name Wakix; 4.5 and $18 \mathrm{mg}$ tablets, authorization valid throughout the European Union) for treating adults with narcolepsy [152]. Currently, in various stages of clinical trials there are about 20 compounds that are histamine $\mathrm{H} 3$ receptor antagonists (ClinicalTrials. gov). Another series of potent quinoline-based human $\mathrm{H} 1$ and $\mathrm{H} 3$ bivalent histamine receptor antagonists, potentially intended for intranasal administration for the treatment of AR-associated nasal congestion, was described at the end of 2016 [153]. It has been suggested that selective histamine $\mathrm{H} 3$ receptor antagonists may be useful in the treatment of multiple disorders, mainly CNS-related [6, 154-157]; among the many others, also use of $\mathrm{H} 3 \mathrm{R}$ antagonists in allergic rhinitis was suggested.

Histamine $\mathrm{H} 3$ receptors are a novel target in the treatment of AR. Two related $\mathrm{H} 3$ receptor antagonists used in clinical studies were more fully characterized: PF-03654746 and PF-03654764 [158]. Single doses of PF-03654746 in combination with fexofenadine caused a reduction in allergen-induced nasal symptoms in a small trial (20 patients) providing an acute nasal allergen challenge with a bolus of ragweed [159]. In turn, combination of fexofenadine with single doses of PF-03654764 was not superior to pseudoephedrine plus fexofenadine in terms of relief of AR-associated nasal symptoms after exposure to ragweed pollen in a larger trial $(n=64)$. However, the PF-03654764-fexofenadine combination improved the Total Nasal Symptom Score (TNSS) compared to placebo [160]. Prophylactic treatment with the other selective H3R antagonist JNJ39220675 (10 mg, single dose) in an early clinical trial relieved allergen-induced nasal congestion by using standard nasal symptom scoring in subjects with allergic rhinitis [161]. Also a dual $\mathrm{H} 1$ and $\mathrm{H} 3$ receptor antagonist designed for intranasal administration as a suspension or solution GSK1004723 and another dual H1R/H3R antagonist, the molecule GSK835726 designed for oral administration [67, 162], as well as some 8-hydroxyquinoline deriva- tives [163], would be very interesting compounds, useful especially in allergic rhinitis. Two new dual antagonists of H1R/H3R, GSK1004723 and GSK835726, have undergone evaluation in clinical trials in allergic rhinitis [162]. Published results demonstrated that a single administration of 10 , 50 and $100 \mathrm{mg} \mathrm{GSK} 835726$ and its repeated administration for three days at a dose of $10 \mathrm{mg}$ had a similar effect as $10 \mathrm{mg}$ of cetirizine [162]. The dual-acting H1R/H3R antagonist GSK1004723 given by the intranasal route has completed two phase 2 clinical trials in human volunteers with allergic rhinitis; results indicate its efficacy (ClinicalTrials.gov, NCT00824356 and NCT00972504). GSK1004723 reduced nasal symptoms of $A R$, but the effect was smaller compared to GSK835726 and cetirizine $[162,164]$. GSK1004723 has been defined as a compound with long action duration and a pharmacokinetic profile suitable for once a day dosing and intranasal application [67].

\section{H4R ligands}

In clinical practice, currently there are no drugs that block the histamine $\mathrm{H} 4$ receptor activity selectively. The first potent and selective H4R antagonist, JNJ7777120, was described in 2003 along with another selective $\mathrm{H} 4 \mathrm{R}$ antagonist that is a $7-\mathrm{NH}_{2}$ substituted indolyl-piperazine derivative [165]. Currently, several dozen H4R ligands are known (most of these are antagonists); a large portion of them were synthesized and described only recently $[166,167]$. Because of the H4R distribution pattern, histamine $\mathrm{H} 4$ receptor antagonists (first of all, JNJ7777120, toreforant [JNJ38518168], JNJ3975897 and ZPL3893787 [formerly PF-3893787]) appear to be useful especially for the treatment of inflammatory and allergic disorders [133].

Clinical reports with H4R antagonists are few, mostly concerning JNJ39758979, a potent and selective H4R antagonist that earlier demonstrated its effectiveness in animal models of dermatitis, pruritus, asthma, and arthritis [85, 118]. Results of studies evaluating H4R antagonists in animal pruritus models indicated that these compounds could also be effective in humans [100-103, 128]. Indeed, the anti-pruritic effect of $\mathrm{H} 4 \mathrm{R}$ antagonists recently has also been demonstrated in clinical studies; the selective H4R antagonist JNJ39758979 alleviated pruritus in patients with atopic dermatitis [134] and inhibited histamine-induced pruritus in healthy volunteers [135]. In the latter study, a role of $\mathrm{H} 4 \mathrm{R}$ in mediating histamine-induced pruritus in humans was examined. Histamine was injected intradermally into the skin of the forearm of subjects given 2 or $6 \mathrm{~h}$ previously a single dose of JNJ39758979 or the H1R antagonist cetirizine, or placebo, and the pruritic response was assessed. JNJ39758979 significantly relieved the 
histamine-induced itch sensation at both 2 and $6 \mathrm{~h}$ after drug administration, cetirizine reduced the pruritic response at $6 \mathrm{~h}$ after treatment, whereas placebo had no effects. JNJ39758979 did not affect wheal and flare reactions, whereas cetirizine reduced both itching and wheal and flare [135] (ClinicalTrials.gov, NCT01068223).

However, in the case of atopic dermatitis, also evidence from clinical studies exists that the H4R antagonist JNJ39758979 can be efficacious against this condition in humans, but potentially dangerous. Two doses of JNJ39758979 (100 and $300 \mathrm{mg}$ ) were compared with placebo in a phase $2 a$ study in adults with moderate AD [136]. JNJ39758979 proved to be effective at week 6 of treatment using eczema area and severity index (EASI) scores, but the study was terminated before the treatment completion as a result of two cases of agranulocytosis. This adverse effect was most likely connected with reactive metabolites of JNJ39758979, not with H4R antagonism [136]. $A$ reduction in the EASI score was noted for both drug doses in comparison with placebo, but the differences were not statistically significant. Secondary endpoints were used to assess pruritus, the most characteristic and common symptom of $A D$, because the EASI score does not provide direct pruritus measurement. Analysis of these endpoints demonstrated strong and significant reduction in the pruritus after JNJ39758979 administration [136]. It can be concluded that other H4R antagonists devoid of serious adverse effects could be effective in the treatment of $A D$, particularly pruritus in its course. Alcaftadine, a potent $\mathrm{H} 1 \mathrm{R}$ antagonist and weak H4R antagonist, is more effective in reducing ocular itch in comparison with olopatadine (H1R antagonist without H4R activity) after conjunctival allergen challenge in humans [168]. Taken together, these results indicate that $H 4 R$ is involved in mediating pruritic responses in humans, and that $H 4 R$ antagonists should be effective in the treatment of pruritic histamine-mediated conditions, such as atopic dermatitis, acute urticaria, allergic rhinitis or allergic conjunctivitis. A good example of a condition where the itching sensation is not well controlled by $\mathrm{H} 1 \mathrm{R}$ antagonists is $\mathrm{AD}$, a common inflammatory pruritic skin disease [169].

Several compounds acting on the $\mathrm{H} 4$ receptor are currently under evaluation in clinical trials. Janssen Pharmaceuticals was exploring the usefulness of toreforant (JNJ38518168), the first H4R antagonist with a generic name in the treatment of asthma (ClinicalTrials.gov, NCT01823016) and rheumatoid arthritis in patients with active disease despite methotrexate therapy (Phase II trials; ClinicalTrials.gov, NCT01862224 and dose range finding study NCT01679951). The asthma study
(NCT01823016) was completed in July 2015, but no study results were posted on ClinicalTrials.gov as of January 15, 2017. Both rheumatoid arthritis studies (NCT01679951 and NCT01862224) were prematurely terminated, the second because of lack of efficacy in the first. Also an efficacy and safety study of JNJ38518168 in adult participants with RA (ClinicalTrials.gov, NCT00941707, sponsor: Johnson \& Johnson) was prematurely terminated due to a single, unexpected serious event (details not given at ClinicalTrials.gov). A clinical study evaluating safety and efficacy of toreforant in patients with moderate to severe plaque-type psoriasis (ClinicalTrials.gov, NCT02295865) was completed, but no study results were posted on ClinicalTrials.gov as of January 15, 2017.

In patients with persistent asthma, also a study with the potent and selective $\mathrm{H} 4 \mathrm{R}$ antagonist JNJ39758979 has been completed (ClinicalTrials. gov, NCT00946569, sponsor: Johnson \& Johnson), but no data had been reported on ClinicalTrials. gov as of January 15, 2017.

Ziarco Pharma (UK) completed a phase II clinical trial for compound ZPL3893787, a H4 antagonist, which confirmed its safety and highly advantageous pharmacokinetic properties in subjects with atopic dermatitis (ClinicalTrials. gov, NCT02424253) [133]. This compound was also assessed in a bronchial allergen challenge study in patients with asthma (ClinicalTrials.gov, NCT00856687, completed). In both cases no study results were posted on ClinicalTrials.gov as of January 15, 2017.

Currently, phase II clinical trials (proof of concept) are being performed, or have been completed, for the spray KD1157 (H4 antagonist, Kalypsys Inc. company; however, the chemical structure of this compound has not been revealed [166] and the website of this firm is not active [as of January 15,2017 , at http://www.biocentury.com/companies/kalypsys_inc]) with the goal of replacing intranasal steroid therapy as the preferred treatment for the relief of congestion in allergic rhinitis [133] and tablets UR63325 (H4 antagonist, Draconis Pharma) in a nasal allergen challenge study in patients with allergic rhinitis (ClinicalTrials.gov, NCT01260753). This latter study was completed, but no study results were posted on ClinicalTrials. gov as of January 15, 2017.

\section{Conclusions}

Histamine receptor ligands are widely used in the treatment of many allergic diseases, e.g. allergic rhinoconjunctivitis, urticaria, or atopic dermatitis. H1R and H2R antagonists are among the most frequently used drugs in self-treatment by patients. Novel generations of H1R antagonists are safer and adverse effects are limited. Appropriate- 
ly administered and when avoiding dangerous interactions, second-generation $\mathrm{H} 1$-antihistamines are relatively safe [13]. However, in many allergic and inflammatory disorders the therapeutic potential of H1RA (as well as H2RA) is relatively low. Therefore, high expectations are placed on novel ligands of histamine $\mathrm{H} 3$ and $\mathrm{H} 4$ receptors. The role of these receptors is not fully understood yet, but the last years have significantly increased our understanding of their functions. Over recent years, researchers have focused on understanding of their location and mechanism of action. Although remaining in the minority, potential peripheral (i.e., not related to the CNS) indications of H3R inhibitors have also been explored (allergic rhinitis, allergen-induced nasal symptoms, possibly also allergic dermatitis). The $\mathrm{H} 4$ receptor is a novel, attractive drug target for a range of conditions, in particular in disorders associated with inflammation or allergies. H4R antagonists presented high efficacy and relative safety in animal models and currently several clinical trials involving them are being conducted or were recently completed. However, there is still much to be examined. The full therapeutic potential of $\mathrm{H} 3$ receptor and $\mathrm{H} 4$ receptor ligands is far from understood. There are many remaining questions, especially with regard to the characterization of the latest discovered $\mathrm{H} 4$ receptor (as to the full complement of cells that express H4R, potential functions beyond inflammation, such as in the CNS or peripheral nervous system). In conclusion, therapeutic prospects are promising (particularly in relieving such a disabling condition as pruritus), but it is too early to be able to say that the treatment will revolutionize the field.

\section{Conflict of interest}

The authors declare no conflict of interest.

\section{References}

1. Emanuel MB. Histamine and the antiallergic antihistamines: a history of their discoveries. Clin Exp Allergy 1999; 29 Suppl 3: 1-11; discussion 12.

2. Katzung BG. Histamine, serotonin, and the ergot alkaloids. In: Basic and Clinical Pharmacology. $12^{\text {th }}$ edn. Katzung BG, Masters SB, Trevor AJ (eds). The McGraw-Hill Companies, Inc.. New York 2012; 273-93.

3. Stegaev V, Sillat T, Porola P, et al. Brief report: first identification of $\mathrm{H} 4$ histamine receptor in healthy salivary glands and in focal sialadenitis in Sjögren's syndrome. Arthritis Rheum 2012; 64: 2663-8.

4. Szeberenyi JB, Pallinger E, Zsinko M, et al. Inhibition of effects of endogenously synthesized histamine disturbs in vitro human dendritic cell differentiation. Immunol Lett 2001; 76: 175-82.

5. Mirossay L, Chastre E, Callebert J, et al. Histamine $\mathrm{H} 2$ receptors and histidine decarboxylase in normal and leukemic human monocytes and macrophages. Am J Physiol 1994; 267: R602-11.
6. Panula P, Chazot PL, Cowart M, et al. International Union of Basic and Clinical Pharmacology. XCVIII. Histamine Receptors. Pharmacol Rev 2015; 67: 601-55.

7. Mahdy AM, Webster NR. Histamine and antihistamines. Anaesth Inten Care Med 2011; 12: 324-9.

8. Hellstrand K, Hermodsson S, Naredi P, et al. Histamine and cytokine therapy. Acta Oncol 1998; 37: 347-53.

9. Stark H. Histamine receptor. BIOTREND Reviews 2007; Review No. 1/11-2007. URL: https://www.biotrend. com/download/5BT_Histamine_Review11_07.pdf (last accessed on January 15, 2017).

10. Wedi B, Wieczorek D, Raap U, Kapp A. Urticaria. J Dtsch Dermatol Ges 2014; 12: 997-1009.

11. Tiligada E, Zampeli E, Sander K, Stark H. Histamine H3 and $\mathrm{H} 4$ receptors as novel drug targets. Expert Opin Investig Drugs 2009; 18: 1519-31.

12. Cataldi M, Borriello F, Granata F, et al. Histamine receptors and antihistamines: from discovery to clinical applications. Chem Immunol Allergy 2014; 100: 214-26.

13. Skidgel RA, Kaplan AP, Erdös EG. Histamine, bradykinin, and their antagonists. In: Goodman \& Gilman's The Pharmacological Basis of Therapeutics. $12^{\text {th }}$ edn. Brunton LL (ed.). The McGraw-Hill Companies, Inc., New York, London 2011; 911-35.

14. Jutel $M$, Akdis M, Akdis CA. Histamine, histamine receptors and their role in immune pathology. Clin Exp Allergy 2009; 39: 1786-800.

15. Hill SJ, Ganellin CR, Timmerman H, et al. International Union of Pharmacology. XIII. Classification of histamine receptors. Pharmacol Rev 1997; 49: 253-78.

16. Haas HL, Sergeeva OA, Selbach O. Histamine in the nervous system. Physiol Rev 2008; 88: 1183-241.

17. Shimamura T, Shiroishi M, Weyand S, et al. Structure of the human histamine $\mathrm{H} 1$ receptor complex with doxepin. Nature 2011; 475: 65-70.

18. Parmentier R, Zhao Y, Perier M, et al. Role of histamine $\mathrm{H} 1$-receptor on behavioral states and wake maintenance during deficiency of a brain activating system: a study using a knockout mouse model. Neuropharmacology 2016; 106: 20-34.

19. Akdis CA, Simons FE. Histamine receptors are hot in immunopharmacology. Eur J Pharmacol 2006; 533: 69-76.

20. Oda T, Morikawa N, Saito Y, et al. Molecular cloning and characterization of a novel type of histamine receptor preferentially expressed in leukocytes. J Biol Chem 2000; 275: 36781-6.

21. Rzodkiewicz P, Wojtecka-Łukasik E, Maśliński S. Role of histamine in rheumatoid diseases. Reumatologia 2010; 48: 49-53.

22. Jutel $M$, Watanabe $T$, Klunker $S$, et al. Histamine regulates T-cell and antibody responses by differential expression of $\mathrm{H} 1$ and $\mathrm{H} 2$ receptors. Nature 2001; 413: 420-5.

23. Sallusto F, Lanzavecchia A. The instructive role of dendritic cells on T-cell responses. Arthritis Res 2002; 4 Suppl 3: S127-32.

24. Salcedo C, Pontes C, Merlos M. Is the $\mathrm{H} 4$ receptor a new drug target for allergies and asthma? Front Biosci (Elite Ed) 2013; 5: 178-87.

25. Dontchev VD, Letourneau PC. Nerve growth factor and semaphorin 3A signaling pathways interact in regulating sensory neuronal growth cone motility. J Neurosci 2002; 22: 6659-69.

26. Takamatsu H, Takegahara N, Nakagawa Y, et al. Semaphorins guide the entry of dendritic cells into the lymphatics by activating myosin II. Nat Immunol 2010; 11 : 594-600. 
27. Ohsawa Y, Hirasawa N. The role of histamine $\mathrm{H} 1$ and $\mathrm{H} 4$ receptors in atopic dermatitis: from basic research to clinical study. Allergol Int 2014; 63: 533-42.

28. Tominaga M, Takamori K. Sensitization of itch signaling: itch sensitization - nerve growth factor, semaphorins. In: Itch: Mechanisms and Treatment. Carstens E, Akiyama T (eds). CRC Press/Taylor \& Francis; Boca Raton (FL) 2014; chapter 17.

29. Zampeli E, Tiligada E. The role of histamine $\mathrm{H} 4$ receptor in immune and inflammatory disorders. Br J Pharmacol 2009; 157: 24-33.

30. Sakai O, Tamada Y, Shearer TR, Azuma M. Involvement of NFkappaB in the production of chemokines by rat and human conjunctival cells cultured under allergenic conditions. Curr Eye Res 2013; 38: 825-34.

31. Enríquez-de-Salamanca A, Calder V, Gao J, et al. Cytokine responses by conjunctival epithelial cells: an in vitro model of ocular inflammation. Cytokine 2008; 44: 160-7.

32. Leonardi A, Curnow SJ, Zhan H, Calder VL. Multiple cytokines in human tear specimens in seasonal and chronic allergic eye disease and in conjunctival fibroblast cultures. Clin Exp Allergy 2006; 36: 777-84.

33. Ohtsu H. Pathophysiologic role of histamine: evidence clarified by histidine decarboxylase gene knockout mice. Int Arch Allergy Immunol 2012; 158 (Suppl 1): 2-6.

34. Dunford PJ, O'Donnell N, Riley JP, et al. The histamine $\mathrm{H} 4$ receptor mediates allergic airway inflammation by regulating the activation of CD4+ $\mathrm{T}$ cells. J Immunol 2006; 176: 7062-70.

35. Church MK, Maurer M. Antihistamines. Chem Immunol Allergy 2014; 100: 302-10.

36. Doenicke A, Moss J, Toledano A, et al. Administration of $\mathrm{H} 1$ and $\mathrm{H} 2$ antagonists for chemoprophylaxis: a double-blind, placebo-controlled study in healthy volunteers. J Clin Pharmacol 1997; 37: 140-6.

37. Muraro A, Roberts G, Worm M, et al.; EAACl Food Allergy and Anaphylaxis Guidelines Group. Anaphylaxis: guidelines from the European Academy of Allergy and Clinical Immunology. Allergy 2014; 69: 1026-45.

38. Runge JW, Martinez JC, Caravati EM, et al. Histamine antagonists in the treatment of acute allergic reactions. Ann Emerg Med 1992; 21: 237-242.

39. Lin RY, Curry A, Pesola GR, et al. Improved outcomes in patients with acute allergic syndromes who are treated with combined $\mathrm{H} 1$ and $\mathrm{H} 2$ antagonists. Ann Emerg Med 2000; 36: 462-8.

40. Tramer MR, von Elm E, Loubeyre P, Hauser C. Pharmacological prevention of serious anaphylactic reactions due to iodinated contrast media: systematic review. BMJ 2006; 333: 675-681.

41. Brockow K, Ring J. Anaphylaxis to radiographic contrast media. Curr Opin Allergy Clin Immunol 2011; 11 : 326-31.

42. Klein PA, Clark RAF. An evidence-based review of the efficacy of antihistamines in relieving pruritus in atopic dermatitis. Arch Dermatol 1999; 135: 1522-5.

43. Akdis CA, Akdis M, Bieber T, et al. Diagnosis and treatment of atopic dermatitis in children and adults: European Academy of Allergology and Clinical Immunology/American Academy of Allergy, Asthma and Immunology/PRACTALL consensus report. J Allergy Clin Immunol 2006; 118: 152-169.

44. Saeki H, Furue M, Furukawa F, et al. Guidelines for management of atopic dermatitis. J Dermatol 2009; 36: 563-577.
45. Thurmond RL. The histamine $\mathrm{H} 4$ receptor: from orphan to the clinic. Front Pharmacol 2015; 6: 65.

46. Metz M, Ständer S. Chronic pruritus: pathogenesis, clinical aspects and treatment. J Eur Acad Dermatol Venereol 2010; 24: 1249-60.

47. Gantz I, Schäffer M, DelValle J, et al. Molecular cloning of a gene encoding the histamine $\mathrm{H} 2$ receptor. Proc Natl Acad Sci USA 1991; 88: 429-33. Erratum in: Proc Natl Acad Sci USA 1991; 88: 5937.

48. Haas HL, Panula P. Histamine receptors. Neuropharmacology 2016; 106: 1-2.

49. Bongers G, Sallmen T, Passani MB, et al. The Akt/ GSK-3beta axis as a new signaling pathway of the histamine H(3) receptor. J Neurochem 2007; 103: 248-58.

50. Bitner RS, Markosyan S, Nikkel AL, Brioni JD. In-vivo histamine $\mathrm{H} 3$ receptor antagonism activates cellular signaling suggestive of symptomatic and disease modifying efficacy in Alzheimer's disease. Neuropharmacology 2011; 60: 460-6.

51. Haas H, Panula P. The role of histamine and the tuberomamillary nucleus in the nervous system. Nat Rev Neurosci 2003; 4: 121-30.

52. Lovenberg TW, Roland BL, Wilson SJ, et al. Cloning and functional expression of the human histamine $\mathrm{H} 3$ receptor. Mol Pharmacol 1999; 55: 1101-7.

53. Anichtchik OV, Peitsaro N, Rinne JO, et al. Distribution and modulation of histamine $\mathrm{H}(3)$ receptors in basal ganglia and frontal cortex of healthy controls and patients with Parkinson's disease. Neurobiol Dis 2001; 8: 707-16.

54. Karlstedt K, Ahman MJ, Anichtchik OV, et al. Expression of the $\mathrm{H} 3$ receptor in the developing CNS and brown fat suggests novel roles for histamine. Mol Cell Neurosci 2003; 24: 614-22.

55. Héron A, Rouleau A, Cochois V, et al. Expression analysis of the histamine $\mathrm{H} 3$ receptor in developing rat tissues. Mech Dev 2001; 105: 167-73.

56. Grandi D, Shenton FC, Chazot PL, Morini G. Immunolocalization of histamine $\mathrm{H} 3$ receptors on endocrine cells in the rat gastrointestinal tract. Histol Histopathol 2008; 23: 789-98.

57. Imamura M, Smith NC, Garbarg M, Levi R. Histamine H3-receptor-mediated inhibition of calcitonin gene-related peptide release from cardiac $C$ fibers. A regulatory negative-feedback loop. Circ Res 1996; 78: 863-9.

58. Yamasaki T, Tamai I, Matsumura Y. Activation of histamine $\mathrm{H} 3$ receptors inhibits renal noradrenergic neurotransmission in anesthetized dogs. Am J Physiol Regul Integr Comp Physiol 2001; 280: R1450-6.

59. Ichinose M, Barnes PJ. Histamine H3 receptors modulate antigen-induced bronchoconstriction in guinea pigs. J Allergy Clin Immunol 1990; 86: 491-5.

60. Ohkubo T, Shibata M. ATP-sensitive K+ channels mediate regulation of substance $P$ release via the prejunctional histamine H3 receptor. Eur J Pharmacol 1995; 277: 45-9.

61. Matsubara T, Moskowitz MA, Huang Z. UK-14,304, R(2)-alpha-methyl-histamine and SMS 201-995 block plasma protein leakage within dura mater by prejunctional mechanisms. Eur J Pharmacol 1992; 224: 145-50.

62. Jókúti A, Hellinger E, Hellinger A. Histamine H4 receptor expression is elevated in human nasal polyp tissue. Cell Biol Int 2007; 31: 1367-70.

63. Werner K, Neumann D, Buschauer A, Seifert R. No evidence for histamine $\mathrm{H} 4$ receptor in human monocytes. J Pharmacol Exp Ther 2014; 351: 519-26.

64. Zhu J, Qu C, Lu X, Zhang S. Activation of microglia by histamine and substance P. Cell Physiol Biochem 2014; 34: 768-80. 
65. Suzuki S, Takeuchi K, Majima Y. Localization and function of histamine $\mathrm{H} 3$ receptor in the nasal mucosa. Clin Exp Allergy 2008; 38: 1476-82.

66. Yokota E, Kuyama S, Sugimoto Y, et al. Participation of histamine $\mathrm{H} 3$ receptors in experimental allergic rhinitis of mice. J Pharmacol Sci 2008; 108: 206-11.

67. Slack RJ, Russell LJ, Hall DA, et al. Pharmacological characterization of GSK1004723, a novel, long-acting antagonist at histamine $\mathrm{H}(1)$ and $\mathrm{H}(3)$ receptors. $\mathrm{Br}$ J Pharmacol 2011; 164: 1627-41.

68. Taylor-Clark T, Sodha R, Warner B, Foreman J. Histamine receptors that influence blockage of the normal human nasal airway. Br J Pharmacol 2005; 144: 867-74.

69. McLeod RL, Rizzo CA, West Jr RE, et al. Pharmacological characterization of the novel histamine $\mathrm{H} 3$-receptor antagonist $\mathrm{N}$-(3,5-dichlorophenyl)- $\mathrm{N}$-[[4-(1H-imidazol-4 -ylmethyl)phenyl]-methyl]-urea (SCH 79687). J Pharmacol Exp Ther 2003; 305: 1037-44.

70. Varty LM, Hey JA. Histamine $\mathrm{H} 3$ receptor activation inhibits neurogenic sympathetic vasoconstriction in porcine nasal mucosa. Eur J Pharmacol 2002; 452: 339-45.

71. Hirasawa N, Ohuchi K. Roles of histamine in the exacerbated allergic dermatitis [Japanese]. Yakugaku Zasshi 2011; 131: 179-84.

72. Hirasawa N, Ohsawa Y, Katoh G, et al. Modification of the picryl chloride-induced allergic dermatitis model in mouse ear lobes by 12-0-tetradecanoylphorbol 13-acetate, and analysis of the role of histamine in the modified model. Int Arch Allergy Immunol 2009; 148: 279-88.

73. Ehling S, Roßbach K, Dunston SM, et al. Allergic inflammation is augmented via histamine $\mathrm{H} 4$ receptor activation: the role of natural killer cells in vitro and in vivo. J Dermatol Sci 2016; 83: 106-15.

74. Grosicki M, Kieć-Kononowicz K. Human eosinophils - potential pharmacological model applied in human histamine H4 receptor research. Curr Med Chem 2015; 22: 2087-99.

75. del Rio R, Noubade R, Saligrama N, et al. Histamine H4 receptor optimizes $\mathrm{T}$ regulatory cell frequency and facilitates anti-inflammatory responses within the central nervous system. J Immunol 2012; 188: 541-7.

76. Hsieh GC, Chandran P, Salyers AK, et al. H4 receptor antagonism exhibits anti-nociceptive effects in inflammatory and neuropathic pain models in rats. Pharmacol Biochem Behav 2010; 95: 41-50.

77. Miadonna A, Milazzo N, Gibelli S, et al. Nasal response to a single antigen challenge in patients with allergic rhinitis - inflammatory cell recruitment persists up to 48 hours. Clin Exp Allergy 1999; 29: 941-9.

78. Thomas M, Edwards MJ, Sawicka E, et al. Essential role of phosphoinositide 3-kinase gamma in eosinophi chemotaxis within acute pulmonary inflammation. Immunology 2009; 126: 413-22.

79. Ling P, Ngo K, Nguyen S, et al. Histamine H4 receptor mediates eosinophil chemotaxis with cell shape change and adhesion molecule upregulation. $\mathrm{Br} J$ Pharmacol 2004; 142: 161-71

80. Shin N, Covington M, Bian D, et al. INCB38579, a novel and potent histamine $\mathrm{H} 4$ receptor small molecule antagonist with anti-inflammatory pain and anti-pruritic functions. Eur J Pharmacol 2012; 675: 47-56.

81. Strakhova MI, Cuff CA, Manelli AM, et al. In vitro and in vivo characterization of A-940894: a potent histamine $\mathrm{H} 4$ receptor antagonist with antiinflammatory properties. Br J Pharmacol 2009; 157: 44-54.

82. Reher TM, Neumann D, Buschauer A, Seifert R. Incomplete activation of human eosinophils via the histamine H4-receptor: evidence for ligand-specific receptor conformations. Biochem Pharmacol 2012; 84: 192-203.

83. Sabroe I, Hartnell A, Jopling LA, et al. Differential regulation of eosinophil chemokine signaling via CCR3 and non-CCR3 pathways. J Immunol 1999; 162: 2946-55.

84. Lim HD, van Rijn RM, Ling P, et al. Evaluation of histamine $\mathrm{H1} 1-, \mathrm{H} 2-$, and $\mathrm{H} 3$-receptor ligands at the human histamine $\mathrm{H} 4$ receptor: identification of 4-methylhistamine as the first potent and selective $\mathrm{H} 4$ receptor agonist. J Pharmacol Exp Ther 2005; 314: 1310-21.

85. Thurmond RL, Chen B, Dunford PJ, et al. Clinical and preclinical characterization of the histamine $\mathrm{H} 4$ receptor antagonist JNJ-39758979. J Pharmacol Exp Ther 2014; 349: 176-84.

86. Yu F, Wolin RL, Wei J, et al. Pharmacological characterization of oxime agonists of the histamine $\mathrm{H} 4$ receptor. J Receptor Ligand Channel Res 2010; 3: 37-49.

87. Mirzahosseini A, Dalmadi B, Csutora P. Histamine receptor $\mathrm{H} 4$ regulates mast cell degranulation and IgE induced FcepsilonRI upregulation in murine bone marrow-derived mast cells. Cell Immunol 2013; 283: 38-44.

88. Thurmond RL, Desai PJ, Dunford PJ, et al. A potent and selective histamine $\mathrm{H} 4$ receptor antagonist with anti-inflammatory properties. J Pharmacol Exp Ther 2004; 309: 404-13.

89. Hofstra CL, Desai PJ, Thurmond RL, Fung-Leung WP. Histamine $\mathrm{H} 4$ receptor mediates chemotaxis and calcium mobilization of mast cells. J Pharmacol Exp Ther 2003; 305: 1212-21.

90. Desai P, Thurmond RL. Histamine H4 receptor activation enhances LPS-induced IL- 6 production in mast cells via ERK and PI3K activation. Eur J Immunol 2011; 41: 1764-73.

91. Jemima EA, Prema A, Thangam EB. Functional characterization of histamine $\mathrm{H} 4$ receptor on human mast cells. Mol Immunol 2014; 62: 19-28.

92. Varga C, Horvath K, Berko A, et al. Inhibitory effects of histamine $\mathrm{H} 4$ receptor antagonists on experimental colitis in the rat. Eur J Pharmacol 2005; 522: 130-8.

93. Cowden JM, Riley JP, Ma JY, et al. Histamine H4 receptor antagonism diminishes existing airway inflammation and dysfunction via modulation of Th2 cytokines. Respir Res 2010; 11: 86.

94. Andersson C, Tufvesson E, Diamant Z, Bjermer L. Revisiting the role of the mast cell in asthma. Curr Opin Pulm Med 2016; 22: 10-7.

95. George L, Brightling CE. Eosinophilic airway inflammation: role in asthma and chronic obstructive pulmonary disease. Ther Adv Chronic Dis 2016; 7: 34-51.

96. Metcalfe DD, Pawankar R, Ackerman SJ, et al. Biomarkers of the involvement of mast cells, basophils and eosinophils in asthma and allergic diseases. World Allergy Organ J 2016; 9: 7.

97. Dunford PJ, Holgate ST. The role of histamine in asthma. Adv Exp Med Biol 2010; 709: 53-66.

98. Beermann S, Glage S, Jonigk D, et al. Opposite effects of mepyramine on JNJ 7777120-induced amelioration of experimentally induced asthma in mice in sensitization and provocation. PLoS One 2012; 7: e30285.

99. Neumann D, Beermann S, Burhenne $H$, et al. The dual $\mathrm{H} 3 / 4 \mathrm{R}$ antagonist thioperamide does not fully mimic the effects of the 'standard' H4R antagonist JNJ 7777120 in experimental murine asthma. Naunyn Schmiedebergs Arch Pharmacol 2013; 386: 983-90.

100. Cowden JM, Zhang M, Dunford PJ, Thurmond RL. The histamine $\mathrm{H} 4$ receptor mediates inflammation and 
pruritus in Th2-dependent dermal inflammation. J Invest Dermatol 2010; 130: 1023-33.

101. Seike M, Furuya K, Omura M, et al. Histamine H4 receptor antagonist ameliorates chronic allergic contact dermatitis induced by repeated challenge. Allergy 2010; 65: 319-26.

102. Matsushita A, Seike M, Okawa $H$, et al. Advantages of histamine $\mathrm{H} 4$ receptor antagonist usage with $\mathrm{H} 1$ receptor antagonist for the treatment of murine allergic contact dermatitis. Exp Dermatol 2012; 21: 714-5.

103. Ohsawa Y, Hirasawa N. The antagonism of histamine $\mathrm{H} 1$ and $\mathrm{H} 4$ receptors ameliorates chronic allergic dermatitis via anti-pruritic and anti-inflammatory effects in NC/Nga mice. Allergy 2012; 67: 1014-22.

104. Mahapatra S, Albrecht M, Behrens B, et al. Delineating the role of histamine-1- and -4-receptors in a mouse model of Th2-dependent antigen-specific skin inflammation. PLoS One 2014; 9: e87296.

105. Bryce PJ, Mathias CB, Harrison KL, et al. The H1 histamine receptor regulates allergic lung responses. J Clin Invest 2006; 116: 1624-32.

106. Morgan RK, McAllister B, Cross L, et al. Histamine 4 receptor activation induces recruitment of $\mathrm{FoxP}^{+} \mathrm{T}$ cells and inhibits allergic asthma in a murine model. J Immunol 2007; 178: 8081-9.

107. Gutzmer R, Mommert S, Gschwandtner M, et al. The histamine $\mathrm{H} 4$ receptor is functionally expressed on TH2 cells. J Allergy Clin Immunol 2009; 123: 619-25.

108. Makala LH, Nagasawa H. Dendritic cells: a specialized complex system of antigen presenting cells. J Vet Med Sci 2002; 64: 181-93.

109. Gutzmer R, Diestel C, Mommert S, et al. Histamine H4 receptor stimulation suppresses IL-12p70 production and mediates chemotaxis in human monocyte-derived dendritic cells. J Immunol 2005; 174: 5224-32.

110. Damaj BB, Becerra CB, Esber HJ, et al. Functional expression of $\mathrm{H} 4$ histamine receptor in human natural killer cells, monocytes, and dendritic cells. J Immunol 2007; 179: 7907-15.

111. Bäumer W, Wendorff S, Gutzmer R, et al. Histamine H4 receptors modulate dendritic cell migration through skin - immunomodulatory role of histamine. Allergy 2008; 63: 1387-94.

112. Gschwandtner M, Rossbach K, Dijkstra D, et al. Murine and human Langerhans cells express a functional histamine $\mathrm{H} 4$ receptor: modulation of cell migration and function. Allergy 2010; 65: 840-9.

113. Gschwandtner M, Mommert S, Koether B, et al. The histamine $\mathrm{H} 4$ receptor is highly expressed on plasmacytoid dendritic cells in psoriasis and histamine regulates their cytokine production and migration. J Invest Dermatol 2011; 131: 1668-76.

114. Dijkstra D, Stark H, Chazot PL, et al. Human inflammatory dendritic epidermal cells express a functional histamine H4 receptor. J Invest Dermatol 2008; 128: 1696-703.

115. Gschwandtner M, Bunk H, Koether B, et al. Histamine down-regulates IL-27 production in antigen-presenting cells. J Leukoc Biol 2012; 92: 21-9.

116. Wang M, Han J, Domenico J, Shin YS, Jia Y, Gelfand EW. Combined blockade of the histamine $\mathrm{H} 1$ and $\mathrm{H} 4$ receptor suppresses peanut-induced intestinal anaphylaxis by regulating dendritic cell function. Allergy 2016; 71: 1561-74.

117. Cowden JM, Yu F, Banie H, et al. The histamine $\mathrm{H} 4$ receptor mediates inflammation and Th17 responses in preclinical models of arthritis. Ann Rheum Dis 2014; 73: 600-8.
118. Savall BM, Chavez F, Tays K, et al. Discovery and SAR of 6-alkyl-2,4-diaminopyrimidines as $\mathrm{H} 4$ receptor antagonists. J Med Chem 2014; 57: 2429-39.

119. Mommert S, Gschwandtner M, Koether B, et al. Human memory Th17 cells express a functional histamine $\mathrm{H} 4$ receptor. Am J Pathol 2012; 180: 177-85.

120. Ballerini C, Aldinucci A, Luccarini I, et al. Antagonism of histamine $\mathrm{H} 4$ receptors exacerbates clinical and pathological signs of experimental autoimmune encephalomyelitis. Br J Pharmacol 2013; 170: 67-77.

121. Bell JK, McQueen DS, Rees JL. Involvement of histamine $\mathrm{H} 4$ and $\mathrm{H} 1$ receptors in scratching induced by histamine receptor agonists in BalbC mice. Br J Pharmacol 2004; 142: 374-80.

122. Dunford PJ, Williams KN, Desai PJ, et al. Histamine $\mathrm{H} 4$ receptor antagonists are superior to traditional antihistamines in the attenuation of experimental pruritus. J Allergy Clin Immunol 2007; 119: 176-83.

123. Yamaura K, Oda M, Suwa E, et al. Expression of histamine $\mathrm{H} 4$ receptor in human epidermal tissues and attenuation of experimental pruritus using $\mathrm{H} 4$ receptor antagonist. J Toxicol Sci 2009; 34: 427-31.

124. Cowart MD, Altenbach RJ, Liu H, et al. Rotationally constrained 2,4-diamino-5,6-disubstituted pyrimidines: a new class of histamine $\mathrm{H} 4$ receptor antagonists with improved druglikeness and in vivo efficacy in pain and inflammation models. J Med Chem 2008; 51: 6547-57.

125. Liu H, Altenbach RJ, Carr TL, et al. Cis-4-(piperazin-1-yl)5,6,7a,8,9,10,11,11a-octahydrobenzofuro[2,3-h]quina zolin-2-amine (A-987306), a new histamine H4R antagonist that blocks pain responses against carrageenan-induced hyperalgesia. J Med Chem 2008; 51: 7094-98.

126. Koenig JR, Liu H, Drizin I, et al. Rigidified 2-aminopyrimidines as histamine $\mathrm{H} 4$ receptor antagonists: effects of substitution about the rigidifying ring. Bioorg Med Chem Lett 2010; 20: 1900-4.

127. Rossbach K, Wendorff S, Sander K, et al. Histamine H4 receptor antagonism reduces hapten-induced scratching behaviour but not inflammation. Exp Dermatol 2009; 18: 57-63.

128. Suwa E, Yamaura K, Oda M, et al. Histamine H4 receptor antagonist reduces dermal inflammation and pruritus in a hapten-induced experimental model. Eur J Pharmacol 2011; 667: 383-8.

129. Sadek B, Stark H. Cherry-picked ligands at histamine receptor subtypes. Neuropharmacology 2016; 106: 56-73.

130. Somma T, Cinci L, Formicola G, et al. A selective antagonist of histamine $\mathrm{H} 4$ receptors prevents antigen-induced airway inflammation and bronchoconstriction in guinea pigs: involvement of lipocortin-1. Br J Pharmacol 2013; 170: 200-13.

131. Bäumer W, Stahl J, Sander K, et al. Lack of preventing effect of systemically and topically administered histamine $\mathrm{H} 1$ or $\mathrm{H} 4$ receptor antagonists in a dog model of acute atopic dermatitis. Exp Dermatol 2011; 20: 577-81.

132. Rosa AC, Pini A, Lucarini L, et al. Prevention of bleomycin-induced lung inflammation and fibrosis in mice by naproxen and JNJ7777120 treatment. J Pharmacol Exp Ther 2014; 351: 308-16.

133. Liu WL. Histamine $\mathrm{H} 4$ receptor antagonists for the treatment of inflammatory disorders. Drug Discov Today 2014; 19: 1222-5.

134. Hisamichi $K$, Murata $Y$, Song $M$ et al. A randomized, placebo-controlled study of H4R antagonist, JNJ39758979, in atopic dermatitis. Abstract P-279. The $25^{\text {th }}$ Spring Meeting of Japanese Society of Allergology 
2013, Yokohama, Japan. Arerugi [Japanese Journal of Allergology] 2013; 62: 456.

135. Kollmeier A, Francke K, Chen B, et al. The histamine $\mathrm{H} 4$ receptor antagonist, JNJ 39758979, is effective in reducing histamine-induced pruritus in a randomized clinical study in healthy subjects. J Pharmacol Exp Ther 2014; 350: 181-7.

136. Murata Y, Song M, Kikuchi H, et al. Phase 2a, randomized, double-blind, placebo-controlled, multicenter, parallel-group study of a H4R-antagonist (JNJ-39758979) in Japanese adults with moderate atopic dermatitis. J Dermatol 2015; 42: 129-39.

137. Bäumer W, Glatzer F, Roßbach K, et al. Histamine in atopic disorders: atopic dermatitis and pruritus. In: Histamine H4 Receptor a Novel Drug Target For Immunoregulation and Inflammation. H. Stark (eds). De Gruytner 2013; 173-99.

138. Chigbu DI, Coyne AM. Update and clinical utility of alcaftadine ophthalmic solution $0.25 \%$ in the treatment of allergic conjunctivitis. Clin Ophthalmol 2015; 9: 1215-25.

139. Namdar R, Valdez C. Alcaftadine: a topical antihistamine for use in allergic conjunctivitis. Drugs Today (Barc) 2011; 47: 883-90.

140. Gallois-Bernos AC, Thurmond RL. Alcaftadine, a new antihistamine with combined antagonist activity at histamine $\mathrm{H} 1, \mathrm{H} 2$, and $\mathrm{H} 4$ receptors. J Recept Ligand Channel Res 2012; 5: 9-20.

141. Nakano Y, Takahashi Y, Ono R, et al. Role of histamine $\mathrm{H} 4$ receptor in allergic conjunctivitis in mice. Eur J Pharmacol 2009; 608: 71-5.

142. Coruzzi G, Adami M, Guaita E, et al. Antiinflammatory and antinociceptive effects of the selective histamine H4-receptor antagonists JNJ7777120 and VUF6002 in a rat model of carrageenan-induced acute inflammation. Eur J Pharmacol 2007; 563: 240-4.

143. Altenbach RJ, Adair RM, Bettencourt BM, et al. Structure-activity studies on a series of a 2-aminopyrimidine-containing histamine $\mathrm{H} 4$ receptor ligands. J Med Chem 2008; 51: 6571-80.

144. Strakhova MI, Nikkel AL, Manelli AM, et al. Localization of histamine $\mathrm{H} 4$ receptors in the central nervous system of human and rat. Brain Res 2009; 1250: 41-8.

145. Cianchi F, Cortesini C, Schiavone N, et al. The role of cyclooxygenase- 2 in mediating the effects of histamine on cell proliferation and vascular endothelial growth factor production in colorectal cancer. Clin Cancer Res 2005; 11: 6807-15

146. Takahashi Y, Kagawa Y, Izawa K, et al. Effect of histamine $\mathrm{H} 4$ receptor antagonist on allergic rhinitis in mice. Int Immunopharmacol 2009; 9: 734-8.

147. Yan ZQ, Zhang RX, Yu SQ, et al. Effect of histamine H4 receptor and its antagonist on allergic rhinitis in rats [Chinese]. Zhonghua Er Bi Yan Hou Tou Jing Wai Ke Za Zhi 2010; 45: 477-80.

148. Hartwig C, Munder A, Glage S, et al. The histamine H4receptor $(\mathrm{H} 4 \mathrm{R})$ regulates eosinophilic inflammation in ovalbumin-induced experimental allergic asthma in mice. Eur J Immunol 2015; 45: 1129-40.

149. Ridolo E, Montagni M, Melli V, et al. Pharmacotherapy of allergic rhinitis: current options and future perspectives. Expert Opin Pharmacother 2014; 15: 73-83.

150. Albu S, Nagy A, Doros C, et al. Treatment of Meniere's disease with intratympanic dexamethazone plus high dosage of betahistine. Am J Otolaryngol 2016; 37: 225-30.

151. Seemungal B, Kaski D, Lopez-Escamez JA. Early diagnosis and management of acute vertigo from vestibular migraine and Ménière's disease. Neurol Clin 2015; 33: 619-28.

152. Wakix. Pitolisant. [Author(s) not stated]. European Medicines Agency. Human medicines. Page last updated on April 13rd, 2016. URL: http://www.ema.europa. eu/ema/index.jsp?curl=pages/medicines/human/medicines/002616/human_med_001955. jsp\&mid=WCOb01ac058001d124 (last accessed on January 15, 2017).

153. Procopiou PA, Ancliff RA, Gore PM, et al. The discovery of quinoline based single-ligand human $\mathrm{H} 1$ and $\mathrm{H} 3$ receptor antagonists. Bioorg Med Chem Lett 2016; 26: 5855-9.

154. Nikolic K, Filipic S, Agbaba D, Stark H. Procognitive properties of drugs with single and multitargeting $\mathrm{H} 3$ receptor antagonist activities. CNS Neurosci Ther 2014; 20: 613-23.

155. Łażewska D, Kieć-Kononowicz K. New developments around histamine $\mathrm{H}(3)$ receptor antagonists/inverse agonists: a patent review (2010 - present). Expert Opin Ther Pat 2014; 24: 89-111.

156. Singh $M$, Jadhav HR. Histamine $H 3$ receptor function and ligands: recent developments. Mini Rev Med Chem 2013; 13: 47-57.

157. Bhowmik M, Khanam R, Vohora D. Histamine H3 receptor antagonists in relation to epilepsy and neurodegeneration: a systemic consideration of recent progress and perspectives. Br J Pharmacol 2012; 167: 1398-414.

158. Wager TT, Pettersen BA, Schmidt AW, et al. Discovery of two clinical histamine $\mathrm{H}(3)$ receptor antagonists: trans-N-ethyl-3-fluoro-3-[3-fluoro-4-(pyrrolidinylmethyl)phenyl]cyclobutanecarboxamide (PF-03654746) and trans-3-fluoro-3-[3-fluoro-4-(pyrrolidin-1-ylmethyl) phenyl]-N-(2-methylpropyl) cyclobutanecarboxamide (PF-03654764). J Med Chem 2011; 54: 7602-20.

159. Stokes JR, Romero FA Jr, Allan RJ, et al. The effects of an H3 receptor antagonist (PF-03654746) with fexofenadine on reducing allergic rhinitis symptoms. J Allergy Clin Immunol 2012; 129: 409-12.

160. North ML, Walker TJ, Steacy LM, et al. Add-on histamine receptor-3 antagonist for allergic rhinitis: a double blind randomized crossover trial using the environmental exposure unit. Allergy Asthma Clin Immunol 2014; 10: 33.

161. Barchuk WT, Salapatek AM, Ge T, et al. A proof-of-concept study of the effect of a novel H3-receptor antagonist in allergen-induced nasal congestion. J Allergy Clin Immunol 2013; 132: 838-46.e1-6.

162. Daley-Yates P, Ambery C, Sweeney L, et al. The efficacy and tolerability of two novel $\mathrm{H}(1) / \mathrm{H}(3)$ receptor antagonists in seasonal allergic rhinitis. Int Arch Allergy Immunol 2012; 158: 84-98.

163. Norman P. New $\mathrm{H} 1 / \mathrm{H} 3$ antagonists for treating allergic rhinitis: WO2010094643. Expert Opin Ther Pat 2011; 21: 425-9.

164. Procopiou PA, Browning C, Buckley JM, et al. The discovery of phthalazinone-based human $\mathrm{H} 1$ and $\mathrm{H} 3$ single-ligand antagonists suitable for intranasal administration for the treatment of allergic rhinitis. J Med Chem 2011; 54; 2183-95.

165. Jablonowski JA, Grice CA, Chai W, et al. The first potent and selective non-imidazole human histamine H4 receptor antagonists. J Med Chem 2003; 46: 3957-60

166. Levoin N, Labeeuw O, Billot X, et al. Discovery of nanomolar ligands with novel scaffolds for the histamine 
H4 receptor by virtual screening. Eur J Med Chem 2017; 5: 565-72.

167. Labeeuw O, Levoin N, Billot X, et al. Synthesis and evaluation of a 2-benzothiazolylphenylmethyl ether class of histamine $\mathrm{H} 4$ receptor antagonists. Bioorg Med Chem Lett 2016; 26: 5263-6.

168. McLaurin EB, Marsico NP, Ackerman SL, et al. Ocular itch relief with alcaftadine $0.25 \%$ versus olopatadine $0.2 \%$ in allergic conjunctivitis: pooled analysis of two multicenter randomized clinical trials. Adv Ther 2014; 31: 1059-71.

169. Williams HC. Clinical practice. Atopic dermatitis. N Engl J Med 2005; 352: 2314-24. 